\title{
KABADUL KULA and the Antiquity of Torres Strait Rock Art
}

Ian J. McNiven ${ }^{1}$, Liam M. Brady ${ }^{2}$ and Anthony J. Barham ${ }^{3}$

\section{Abstract}

Excavations directly below a painted panel at Kabadul Kula rock art site on the island of Dauan, northern Torres Strait, revealed buried fragments of ochre pigment to a depth of $59 \mathrm{~cm}$. A series of AMS ${ }^{14} \mathrm{C}$ dates indicate that most of the ochres and all pieces of facetted ochre were deposited between 1200 and 1400 years ago. Located in a moist tropical environment where the potential for erosion and bioturbation is high, the stratigraphic integrity of the deposit was tested by micromorphological analysis of sediments. Assessment of vertical changes in the size of stone artefacts and sediment particle sizes suggest strongly that this restricted timeframe for ochre use is reliable and not a taphonomic illusion created by post-depositional disturbance. These in situ ochres are associated with an early phase of painting at the site and represent the oldest dates currently available for Torres Strait rock art.

\section{Introduction}

During the past decade major advances have been made in documenting the form, distribution and meaning of Torres Strait rock art (e.g. Brady 2005, 2006, 2007, 2008; Brady and Kaurareg Aboriginal Community 2007; Brady et al. 2003, 2004; David et al. 2001, 2003, 2004a; McNiven and David 2004; McNiven et al. 2000, 2002, 2004) (Figure 1). While over the same time period understandings of the human history of the archipelago have been pushed back to 9000 years ago (David et al. 2004b) and marine specialisation back to 4000 years ago (Crouch et al. 2007; McNiven et al. 2006), insights into the antiquity of the region's rock art have been less forthcoming. As Brady (2007:112) points out, developing a regional rock art chronology is necessary 'to understand how rock-art from Torres Strait fits into the occupational trends already established' for the region.

Until know, inferences of the antiquity of Torres Strait rock art have been based on two approaches. First, general comments have been made on the likely recent age of much of the region's rock paintings given poor preservation conditions. For example, Brady and Kaurareg Aboriginal Community $(2007: 21,24)$ posit that given the 'harsh coastal climate of the Torres Strait region' it is likely that most of the known rock art sites of southwest Torres Strait date only to the past 'few hundred years'. Second, McNiven and David (2004:221) advocate that a fruitful avenue would be 'indirect dating by excavation of in-situ ochres beneath paintings' This approach was first applied to Turao Kula site on the island of Mua, where charcoal associated with a small patch of red ochre powder excavated from XU3 at a depth of $1.7-4.6 \mathrm{~cm}$ below the surface dated to $325 \pm 61$ BP (Wk-9943) (David et al.

\footnotetext{
Programme for Australian Indigenous Archaeology, School of Geography and Environmental Science, Monash University, Clayton, VIC 3800, Australia lan.McNiven@arts.monash.edu.au

${ }^{2}$ Archaeology, M405, School of Social and Cultural Studies, University of Western Australia, 35 Stirling Highway, Crawley, WA 6009, Australia Imbrady@cyllene.uwa.edu.au

${ }^{3}$ School of Archaeology and Anthropology, Australian National University, Canberra, ACT 0200, Australia anthony.barham@anu.edu.au
}

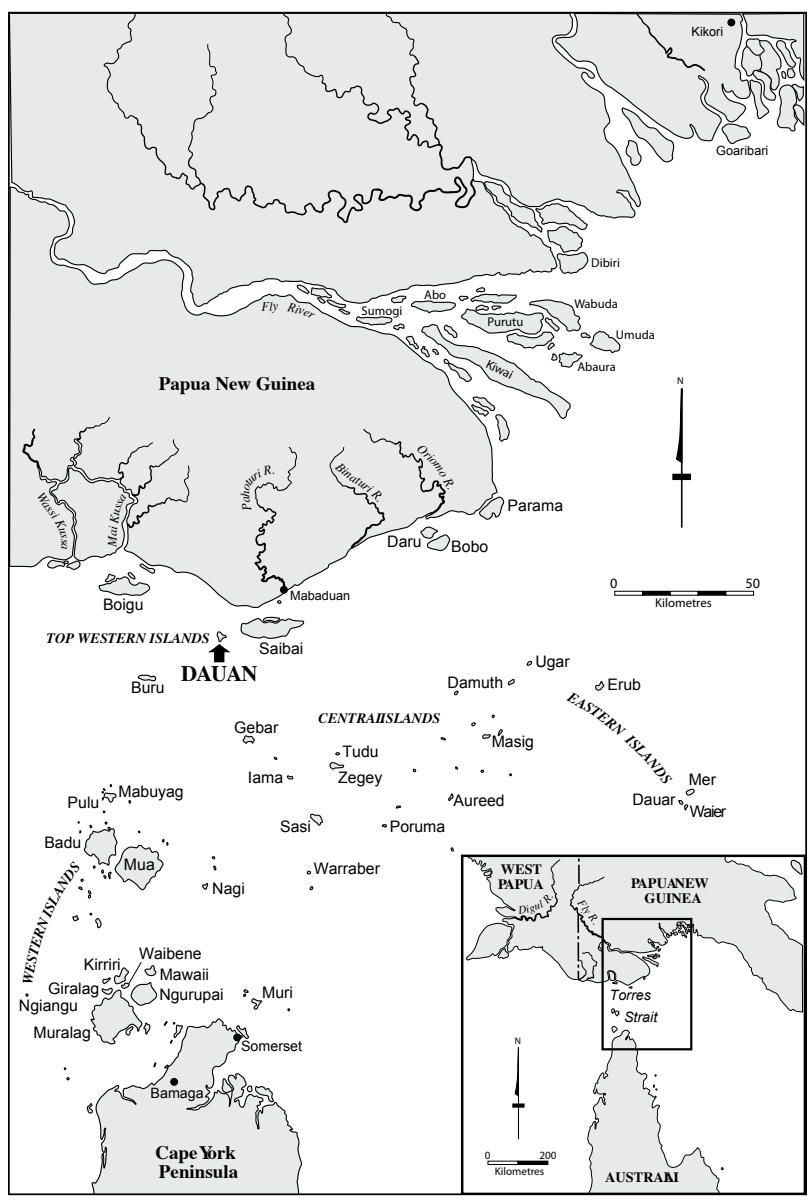

Figure 1 Torres Strait.

2004a). As the powdered ochre was the only ochre excavated from the pit and was 'of the same colour as the paintings' located above, David et al. (2004a:168) suggest the buried ochre relates to the paintings and that both date to somewhere between $\mathrm{AD}$ 1400 and 1850 . The inferred recent antiquity for those paintings is consistent with oral history for the site. Similarly, McNiven et al. (2008) suggest that a major peak in in situ ochre in the upper levels of Tigershark Rockshelter on Pulu islet dated c.500700 years ago most likely corresponds to the period of rock art production at the site. Until now, Tigershark Rockshelter was the earliest date available for Torres Strait rock art.

In this paper, we explore further the use of excavated in situ ochre to provide insights into the antiquity of Torres Strait rock art. The focus of our research is Kabadul Kula rock art site located on the island of Dauan in northern Torres Strait 10km south of the Papua New Guinea coast (Figure 1). Kabadul Kula is the most comprehensively-recorded rock art site in Torres Strait and the place where the process of computer enhancement of digital photographs of faded rock paintings was first applied and developed for the region (Beckett 1963; David et al. 2001, 2003; Laade 1971:xxi; Lawrie 1970:143-147; McNiven et al. 2000, 2002, 2004; Vanderwal 1973:182). Our excavations follow 


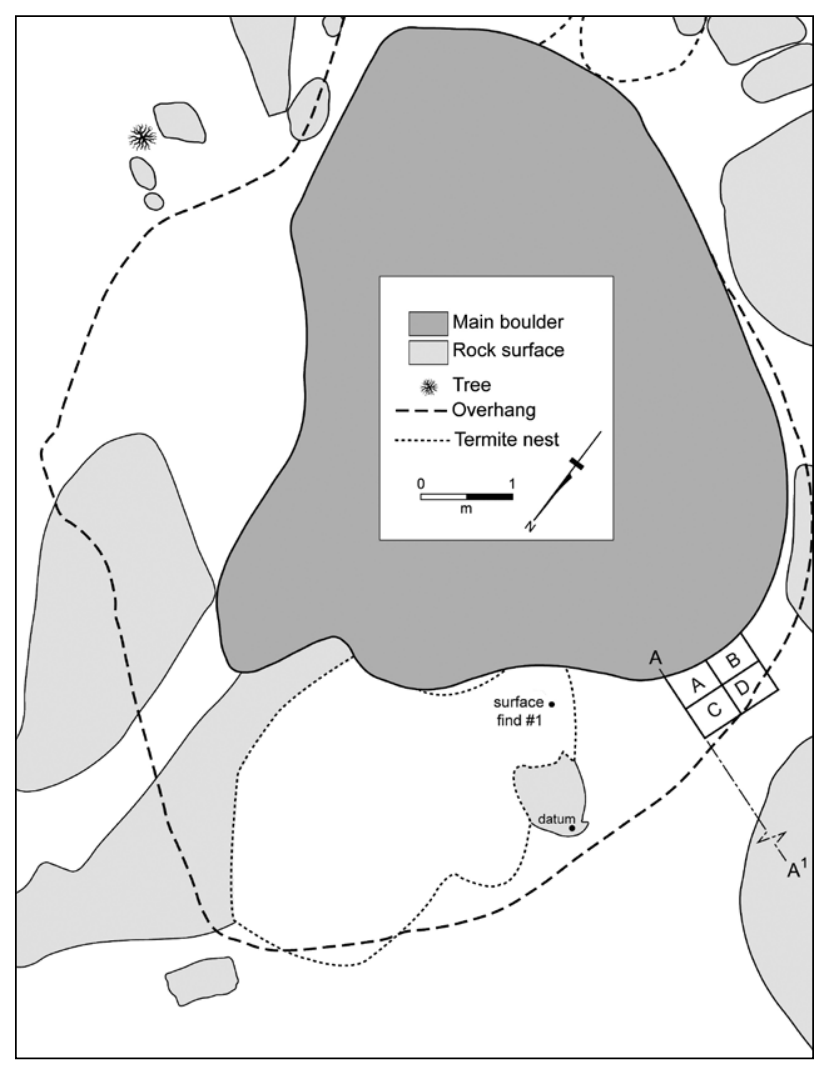

Figure 2 Plan of Kabadul Kula.

a recommendation by McNiven et al. (2004:248) that further insights into the antiquity of rock art at the site will require 'highly controlled and fine-grained excavation of archaeological sediments below the paintings and date layers containing spalls with paint and/or lumps of ochre'. However, as a method of dating rock art, the in situ ochre technique is premised on a series of assumptions with associated limitations. As the following discussion reveals, recognition and acknowledgement of these limitations allows identification of conditions that need to be met to increase the plausibility and strength of inferences concerning the age of associated rock paintings.

\section{In Situ Ochre and Rock Art Dating}

The in situ ochre technique is an established method of providing indirect insights into the age of rock paintings (Keyser 2001:118-119; McDonald 2006:77; Morwood 2002:128-130). The technique is based on the plausible assumption that as rock paintings are created, associated ochre pigments will be left behind on the ground surface below and eventually buried and incorporated into stratified archaeological deposits. If these surface ochre fragments are buried with charcoal or other datable materials of similar age, then dating of these materials can provide an estimate of the timing of ochre deposition and hence rock art production. Relatively fast net sediment accumulation will serve to maintain such contextual association. A slowing of net sediment accumulation or stillstands with pedogenesis will serve to progressively complicate the time-discard component associations, especially if sediment upcast or vertical mixing by invertebrates is an important process at the site (Canti 2003, 2006; Morin 2006; Stein 1983). A further complicating factor is that in situ ochres may also be associated with painting movable artefacts and even human bodies (Chippindale and Taçon
1998:101; Flood and Horsfall 1986:27; Smith et al. 1998:280). As such, the question arises as to whether dated in situ ochres are providing insights into a painted rock surface (i.e. rock art) and/ or painted objects. Thus, the link between in situ ochres and rock art in archaeological contexts is not straightforward.

Despite assumptions and potential limitations of the in situ ochre dating technique, it has been used to provide chronological parameters for Australian Aboriginal rock art (e.g. Attenbrow et al. 1995:116; Cole et al. 1995:154; David 2002:192; David et al. 1994; Macintosh 1965:97; McDonald 2008; Rosenfeld and Smith 2002:117-118; Smith and Ross 2008:56-57; Smith et al. 1998:280). Recently, McDonald and Veth (2008; see also Veth et al. 2001:15) provided case studies from the Western Desert where partial overlaps in chronology for in situ ochres and direct AMS dates on rock paintings provided some empirical verification for the reliability of dated in situ ochres as an indirect indicator of the antiquity of associated rock art.

The likelihood that in situ ochres were associated with the production of rock art can be increased considerably if the following six conditions are met. First, the in situ ochres are excavated from sediments located directly beneath panels of rock art (e.g. David and Lourandos 1999:113; Smith et al. 1998:280). Second, the in situ ochres are the same as ochres used in the rock art (e.g. based on geochemical fingerprinting) (e.g. Clottes and Courtin 1996:165; O'Connor and Fankhauser 2001; cf. Bednarik 2007:120; d'Errico and Vilhena Vialou 2007:188). Third, the in situ ochres are associated with fragments of rock art that broke away from adjacent panels (e.g. David et al. 1990; O'Connor and Fankhauser 2001). Fourth, the in situ ochres are temporally restricted to a narrow timeframe (or a low number of frequency peaks), thus narrowing options for the timing of rock art and decreasing the chances of in situ ochres dating other forms of painting activity (e.g. David and Chant 1995:385; Morwood and Dagg 1995). For example, if in situ ochres span thousands of years, it is difficult to know whether or not rock art production dates to all or only part of this time span. Fifth, the narrow timeframe and associated ochre concentration/peak is not a sedimentary consequence of selective erosion of sedimentary matrix in the form of a lag deposit of ochre or a remnant ochre deposit created by decay and/or erosion of ochres from surrounding levels (cf. Hiscock 2008:254; McDonald 2008:128). Sixth, any concentration of ochre (or other coarse clastic materials such as lithic artefacts) is not an artefact of post-depositional disturbance or fine sediment upcasting by microfauna (e.g. as coarse clastic 'stone lines' created $10-20 \mathrm{~cm}$ below surface by bioturbation) (Binet and Le Bayon 1999; Brown et al. 2004; Canti 2003, 2006:114-115; Darwin 1881; Madge 1969). These six conditions guide our analysis of in situ ochres at Kabadul Kula.

\section{Kabadul Kula}

Kabadul Kula is located on the northeast coast of Dauan approximately $30 \mathrm{~m}$ from the sea (Figures 2-4). It is a large granite boulder with a maximum length of $8 \mathrm{~m}$ and maximum height of $5.5 \mathrm{~m}$. Paintings are located across two panels spanning the lower sections of the northern and northwestern faces of the boulder (see Brady 2005:131-154; McNiven et al. 2004 for details). A low density scatter of stone artefacts and marine shells occurs across the ground surface fronting the painted panels. The ground surface at the base of the boulder and painted panels lies within 


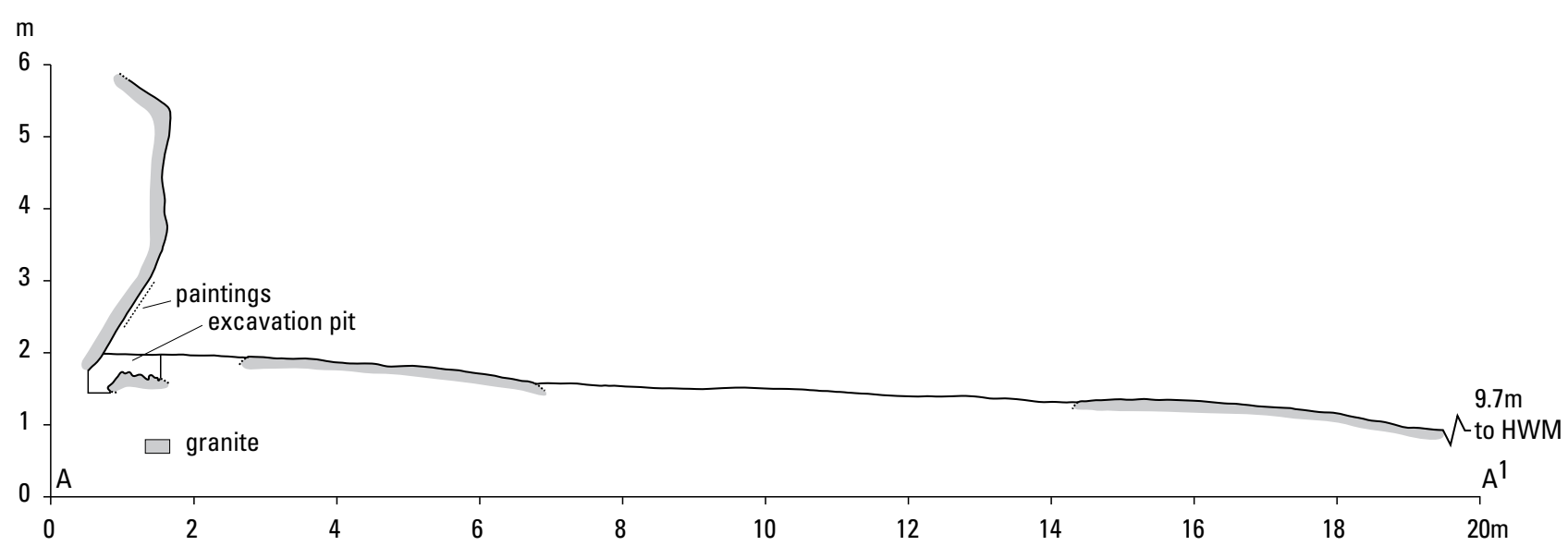

Figure 3 Cross-section of Kabadul Kula.

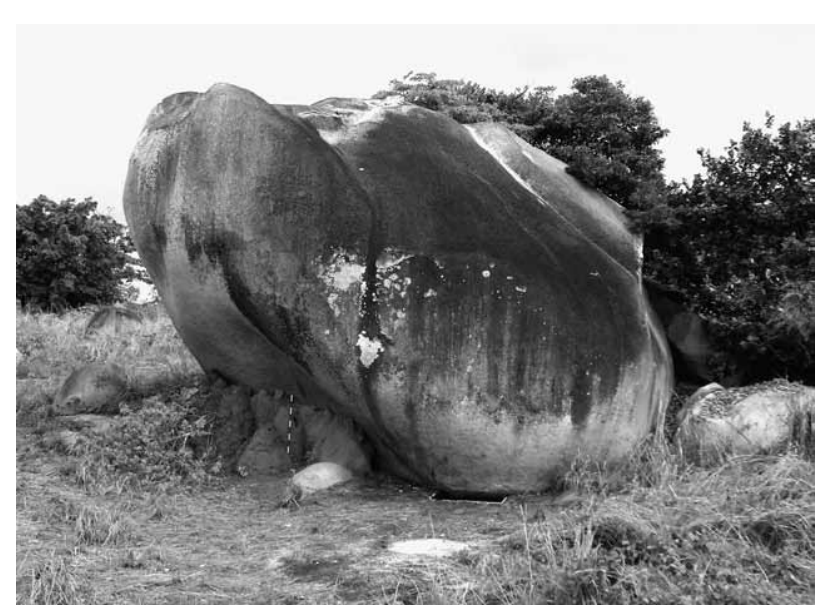

Figure 4 Kabadul Kula after excavation and before removal of termite nest, looking southeast, 17 November 2007. Scale in $10 \mathrm{~cm}$ units (Photograph: Ian J. McNiven).

$2-3 \mathrm{~m}$ of Highest Astronomical Tides (HAT). The northern side of the boulder exhibits a large termite nest that is slowly advancing up the boulder wall and in some places is covering paintings. Long grass up to $2 \mathrm{~m}$ high surrounds the site.

McNiven et al. (2004) report 44 paintings at the site, all made using red ochre paint. Key paintings include a dogai female spirit being (anthropomorph), an anthropomorph with a turtleshell headdress, a row of dancing anthropomorphs, a crayfish, a fish/dugong, canoes, and various geometrics. Many paintings only became clear after computer enhancement. Subsequent rerecording of the site using a more powerful camera revealed additional heavily deteriorated images, increasing the total number of paintings at the site to 47 (Brady 2005:134).

Local oral history associates Kabadul Kula with a group of Papuan raiders from Kiwai Island to the east who stopped at the site and executed paintings before launching an attack on the nearby village and killing and decapitating many Dauanalgal (people of Dauan) (see Lawrie 1970:143-147 for details). The raiders attacked the Dauanalgal as punishment for eating a pig loaned to them from villagers on the adjacent mainland of Papua New Guinea. As differences in weathering and superimposition of paintings indicate at least two phases of painting, McNiven et al. (2004:248-249) conclude that Kabadul Kula includes more phases of painting than just those created by the Kiwai raiders. Since oral history does not mention subsequent painting events at Kabadul Kula, McNiven et al. (2004:248) hypothesise further
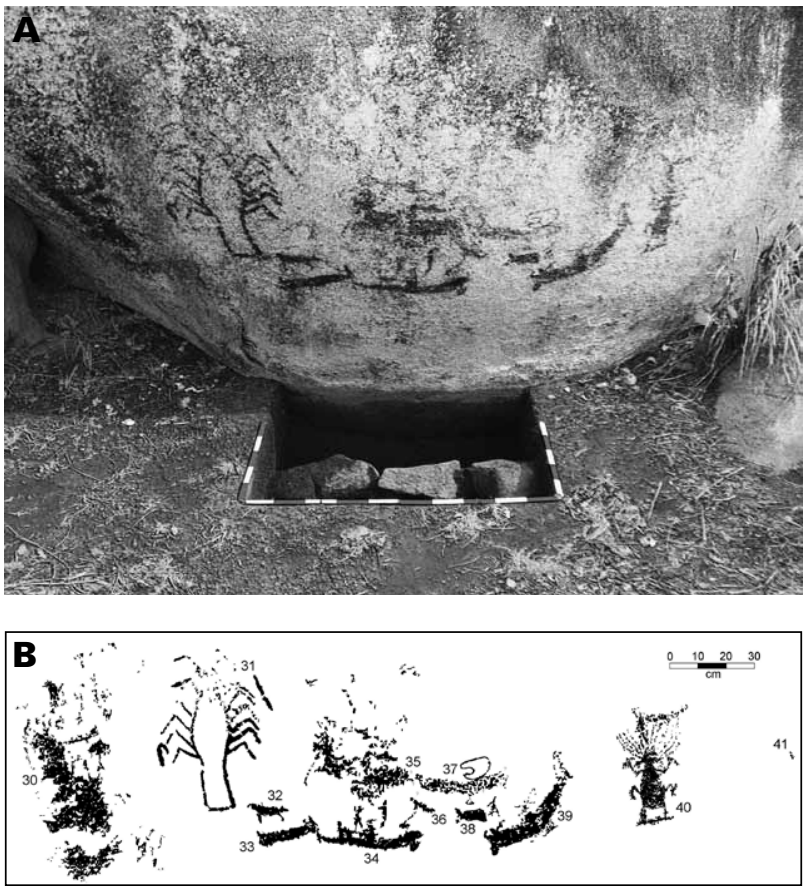

Figure 5 (A) Computer-enhanced photograph of northwest rock art panel at Kabadul Kula showing excavation pit with alignment of three granite boulders (Photograph: Ian J. McNiven). (B) Drawing of paintings based on computer enhancements (from McNiven et al. 2004:Figure 6).

that the Kiwai raiders may have been the last painters at the site whereupon they 'inscribed their own symbols onto an already marked rock in the Dauan landscape'. That is, while the most recent painting phase represents that of the Kiwai raiders, earlier phases of painting also exist at Kabadul Kula.

In November 2007 we carried out excavations at the site in an attempt to obtain buried fragments of ochre associated with datable charcoal that could shed further light on the age of paintings. The excavations were undertaken in conjunction with a project funded by the Department of the Environment and Water Resources through its National Indigenous Heritage Program to remove the large termite nest and help restore sections of the northern painted panel covered by termite nest in recent years. Technical aspects of the conservation work were directed by Andrew Thorn (2008). Our work at Kabadul Kula represents a partnership research project with the people of Dauan. 


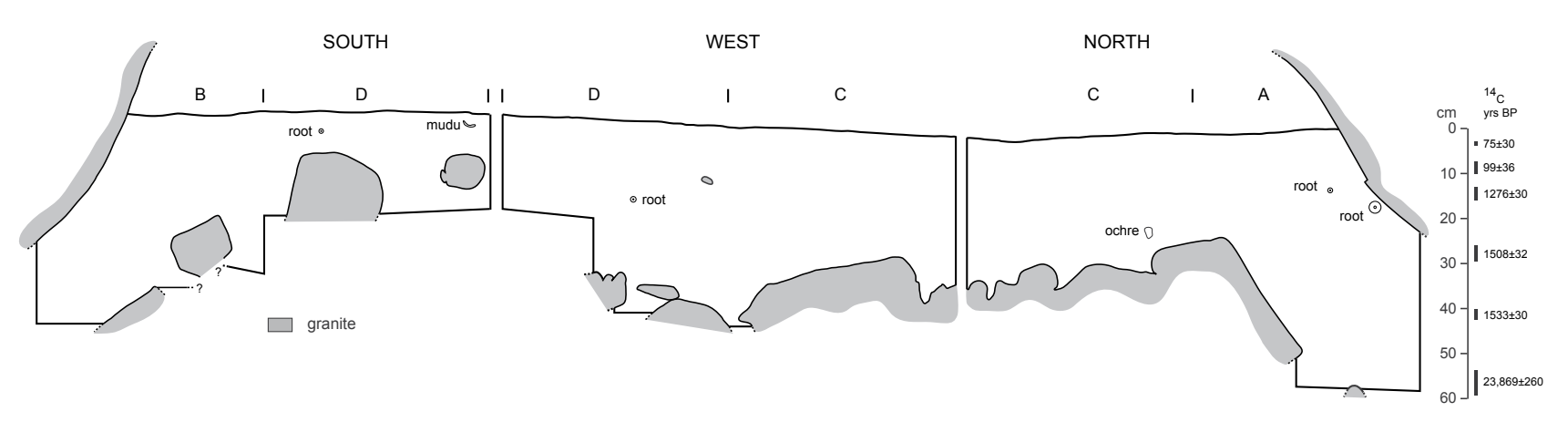

Figure 6 Stratigraphy of Squares A, B, C and D, Kabadul Kula.

\section{Excavation}

The excavation pit was positioned against the northwest rock art panel to avoid termite-disturbed deposits fronting the northern rock art panel (Figures 2-5). The $1 \mathrm{~m} \times 1 \mathrm{~m}$ excavation pit was divided into four $50 \mathrm{~cm} \times 50 \mathrm{~cm}$ Squares (A to D) with Squares A and $B$ located against the rock wall of the shelter. Excavation was undertaken using arbitrary spits or Excavation Units (XUs), with all attempts made to avoid mixing different stratigraphic layers within the same XU. The number of XUs and maximum depth of excavation in each square is as follows: Square A (20 XUs, $59.2 \mathrm{~cm}$ ); Square B (18 XUs, $47.7 \mathrm{~cm}$ ); Square C (17 XUs, $44.3 \mathrm{~cm}$ ); and Square D (17 XUs, $43.9 \mathrm{~cm})$. Excavation continued to granite bedrock across most of Squares $\mathrm{C}$ and $\mathrm{D}$ and to the limit of accessibility in Squares A and B (Figure 6). A datum point was established on a localised high point on the western end of a large granite boulder located $1.5 \mathrm{~m}$ north of the excavation pit. The datum is elevated $23 \mathrm{~mm}$ above the surface elevation of the northwest corner of Square C.

XUs were thin to increase chronological and stratigraphic control, with a mean thickness of $2.7 \pm 0.12 \mathrm{~cm}$ (range: $0.5-5.5 \mathrm{~cm}$ ). The weight and volume of each $\mathrm{XU}$ was recorded and depth elevations were taken at the corners and centre of each square at the beginning and end of each XU. All excavated deposit was wet sieved through $2.1 \mathrm{~mm}$ mesh. Samples of $<2.1 \mathrm{~mm}$ dry sieved sediment were taken for each XU. A total of $488.1 \mathrm{~kg}$ of deposit with a volume of 427 litres was excavated. Squares were backfilled with sediments from the sieve spoil heap located offsite $25 \mathrm{~m}$ to the west.

\section{Stratigraphy and Stone Structure}

Sediments were visually poorly stratified, homogeneous, granitic variably stoney silty loams and stoney sandy loams (Marshall 1947; McDonald et al. 1998) ranging in colour from dark grey to black depending on moisture content. The consolidated and hard-setting silty and clay-rich deposit made excavation difficult except when rain moistened and softened sediments. The absence of stratigraphic changes observed while digging and within the pit sections is consistent with textural uniformity throughout the deposit and bioturbation (see below). Pedal development was minimal, with no recognisable Ah horizon, consistent with rapid biodegradation of near-surface organic matter. Evidence of clay illuviation, with incipient Bt formation, was likewise absent. The lack of soil horizon development classifies the sequence as an incipient Entisol (FAO-UNESCO 1988).

The sequence was stratified with respect to some sediment matrix components, particularly cultural materials and coarser clastic stone material. Cultural materials (charcoal, stone artefacts, bone and ochre) were found throughout the deposit, but marine shells were restricted mostly to the upper four XUs. Land snail shells $(3.5 \mathrm{~g})$ were found intermittently between XUs 1 and $14(0-36 \mathrm{~cm}$ below the surface). Small fragments of pumice (7.3g) were restricted to XUs 4 to $16(5-46 \mathrm{~cm}$ below the surface) confirming an absence of mixing or upcast into near-surface layers. Measured pH values (methods following Rayment and Higginson 1992) of sediments from Square A were relatively constant and acidic, ranging from 4.45 to 5.36. Overall, the consolidated nature of sediments coupled with minor evidence for bioturbation disturbance observed during excavation suggests the deposit exhibits reasonable stratigraphic integrity with little post-depositional (vertical) movement of cultural materials. Field observations of soil and sediment sequence properties are broadly supported by particle size analyses and radiocarbon dating; analysis of vertical changes in cultural materials suggests some post-depositional disturbance of sediments (see below).

Coarser pebble gravels $(>4 \mathrm{~mm})$ and cobbles and rock clasts ( $>64 \mathrm{~mm}$ ) formed a significant lag to the deposit in XU1 and also proportionally increased towards the base of the sequence (Figure 7). The surface lag is consistent with sediments which form during periodic wet season run-off on coarser-textured regolith on granite slopes on Dauan, especially on slopes subject to dry season burning (Humphreys and Mitchell 1983). XUs 4 to 12 were largely clast-free deposits, but XUs 13 to 20 represent loams which form a trapped infill within a complex nest of unweathered granitic boulders sitting on an underlying (unweathered) bedrock surface. The excavated coarser clastic rocks in XUs 15 to 20 derive from that boulder unit. Higher levels of the natural basal boulder unit have been deliberately repositioned by people. An alignment of three granite boulders was uncovered across the middle of the pit extending horizontally between the north and south sections (Figure 5). The northern and southern stones were partially exposed while the middle stone was fully uncovered. Undercutting of the northern and middle stones indicates that they are resting on granite bedrock. The stones range in depth from $9 \mathrm{~cm}$ (top) to at least $50 \mathrm{~cm}$ (bottom) below the surface. While it is unknown at what point in the history of Kabadul Kula the stone alignment was constructed, it is at least as old as the age of sediments burying basal sections of the feature (see below). Why the alignment was built remains a mystery.

\section{Interpretation of the Excavated Stratigraphy}

The sequence properties suggest that sediment accumulation has been relatively rapid, onto an underlying clean and unweathered bedrock surface. The basal boulder bed is interpreted as residual, 
and acted as a trap for finer sediment accumulation and the cultural sequence. We speculate that the formation of the boulder bed and absence of saprolite/older soils in the basal sequence over clean bedrock reflects marine wave erosion during a higher sea-level stand at the site, possibly in the mid-Holocene. The excavated 50-60 cm deep cultural deposit has then accumulated in association with periodic washed inputs of sandier sediments (from upslope), possibly supplemented by seasonal shortdistance wind-blown sand inputs from the adjacent shoreline. Discard of ochre, artefacts and charcoal into the accumulating sequence under the rock panel formed the cultural sequence, which has retained some primary stratification. Pedogenesis is minimal because all but the lower boulder bed has accumulated in the last few thousand years (see below).

\section{Sediment Particle Size}

Vertical distribution of the frequency of $<10 \mathrm{~cm}$ rocks (mostly in the form of granite gravel) recovered from the $2.1 \mathrm{~mm}$ mesh sieve reveals few vertical changes (Figure 7), other than the surface lag in XU1. The absence of obvious concentrations of rocks through the main body of the deposit is consistent with an absence of lag deposits associated with old erosional surfaces and stonelines produced at the base of biomantles (zone of bioturbation) (Balek 2002; Brown et al. 2004; Johnson 2002).

Laboratory particle size analysis of sediments $(<1000 \mu \mathrm{m})$ produced a more nuanced picture of depositional processes (see Appendix). Non-chemically pre-treated sediment samples from Square A reveal vertical changes in the proportion of sand (Figure 8). Major peaks in sand fraction occur in XUs 2, 8 and 16. The increased sand content in thin beds could reflect either selective removal of finer sediments (silts and clays) (e.g. through weak illuviation) and/or increased addition of sands. Given the proximity of the site to slopes down which episodic wash occurs, and also the proximity to the shoreline, a combination of episodic colluvial and/or local aeolian input is inferred.

A second sediment analysis involved chemically pretreating samples with $30 \%$ hydrogen peroxide $\left(\mathrm{H}_{2} \mathrm{O}_{2}\right)$ at $80^{\circ} \mathrm{C}$ to remove organic matter prior to particle size determination. Figure 8 reveals an increase in the proportion of sand up-profile, relative to a decrease in silts. Measured clay content varies little $(20 \pm 3 \%)$. This increase in sand fraction from XU15 to XU1 is again interpreted as reflecting primary deposition, not pedogenesis. Overall, the sedimentary sequence at Kabadul Kula shows no radical changes in deposition or major erosional events creating residual lag deposits.

\section{Cultural Materials}

Cultural materials recovered from Squares A to D include: bone (10.0g), marine shell (192.2g), charcoal $(26.7 \mathrm{~g})$, stone artefacts (296.8g, n=1397) and ochre (205.5g) (Figure 9). Most bone (82\%) was recovered from XUs 1 to 4 and nearly all (91\%) was identified as large vertebrates with only trace occurrences of fish $(0.7 \mathrm{~g})$ and small vertebrates $(0.2 \mathrm{~g})$. Ethnographic and previous archaeological research on Dauan suggest the large vertebrate bone represents turtle and/or dugong (see McNiven 2006). However, some of the bone may also represent pig as a right femur central shaft fragment of an immature pig was recovered from the surface of the site during removal of the termite nest (Surface Find \#1 - see Figure 2).

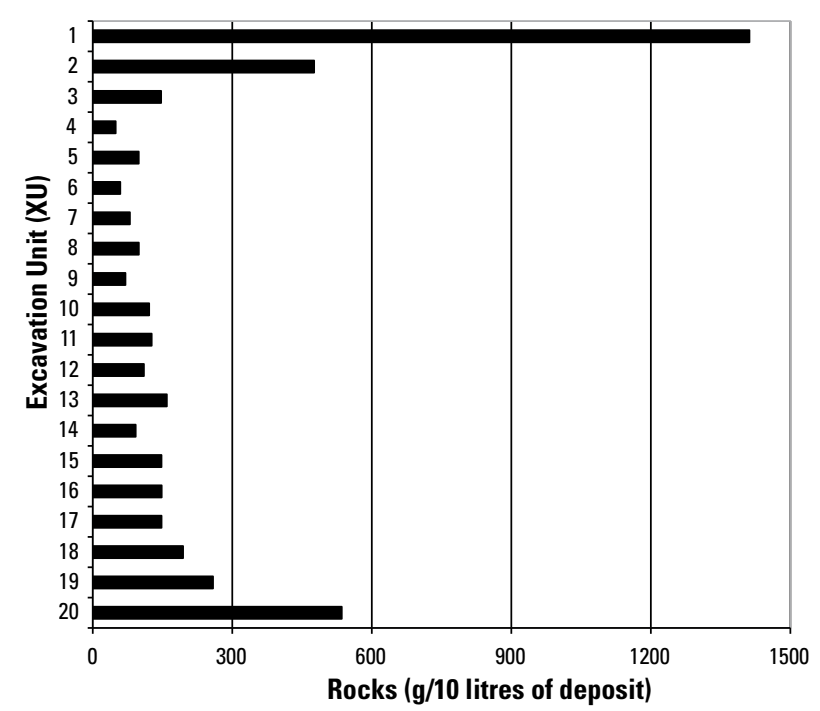

Figure 7 Vertical changes in rocks, Squares A and B combined, Kabadul Kula.
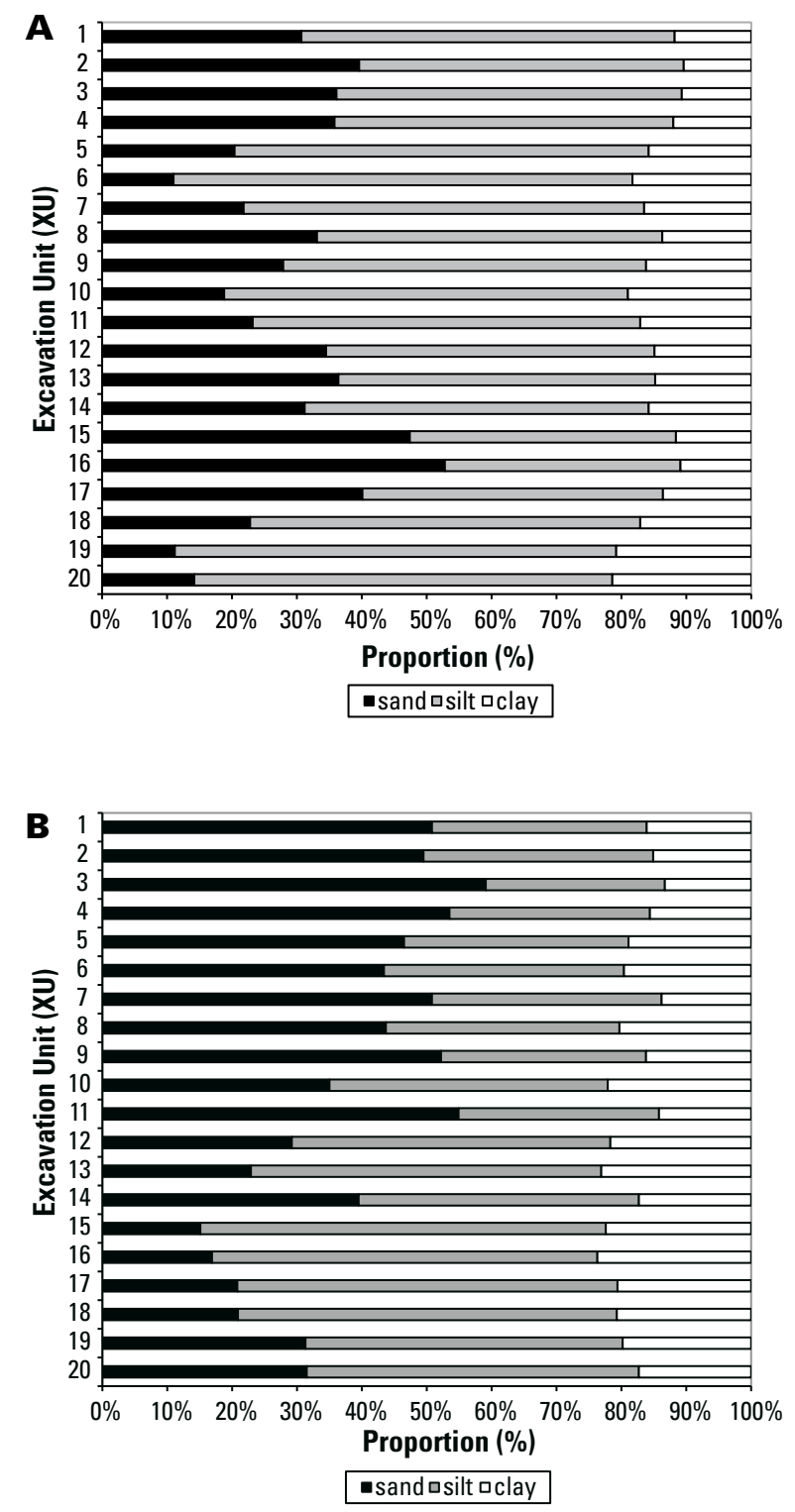

Figure 8 Particle size distribution of untreated (A) and chemically pretreated (B) sediments, Square A, Kabadul Kula. 

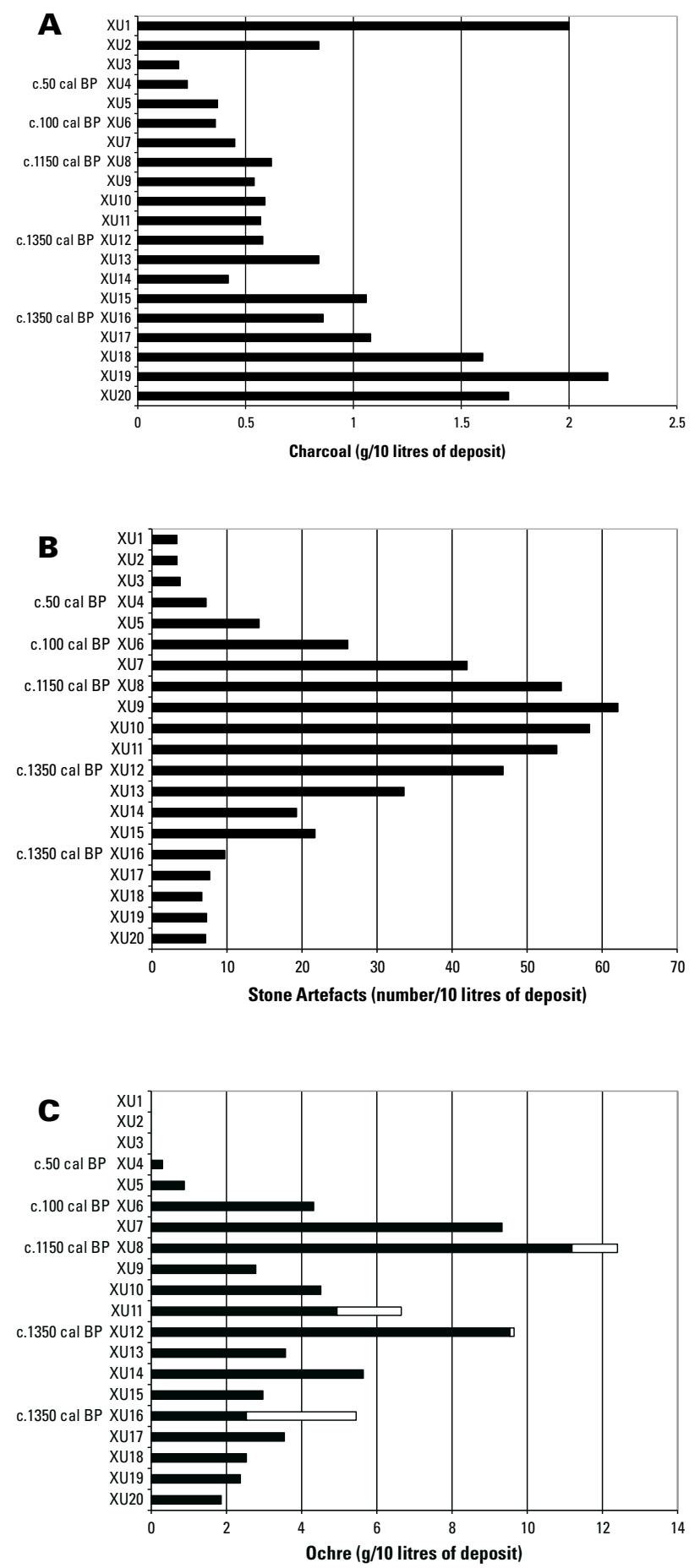

Figure 9 Vertical changes in charcoal (A), stone artefacts (B) and ochre frequency (C) by XU, Squares A to D combined, Kabadul Kula. For C: black=non-facetted, white=facetted.

Almost all marine shell (99.8\%) was recovered from XUs 1 to 4. A MNI of only six marine shells was identified: locally available mudu (Anadara antiquita) $(\mathrm{MNI}=5)$ and akul (Polymesoda erosa) $(\mathrm{MNI}=1)$. Charcoal density is relatively high in surface levels (XUs 1 and 2) and basal levels (XUs 18 to 20). The fish bone assemblage was represented by teeth only $(\mathrm{NISP}=12)$. Most of the teeth $(\mathrm{NISP}=8)$ were identified as Scaridae (wrasse) lower pharyngeals (Square-XU: B-12, C-9, C-11, C-12 and D-9) with one pharyngeal cluster (C-8) and two conical teeth (C-14b) comparing favourably with Labridae (parrotfish).
Flaked stone artefacts peak in density in XU9. Preliminary analysis of flaked stone artefacts reveals an assemblage dominated by small flakes $(<1 \mathrm{~cm}$ long) with most artefacts manufactured from quartz $(92.2 \%, \mathrm{n}=1288)$ followed by minor amounts of volcanics $(7.6 \%, \mathrm{n}=106)$ and chert $(0.2 \%, \mathrm{n}=3)$. Nearly all ochre (98.3\%) was recovered from XUs 6 to 20 with peak density in XU8.

In summary, the upper sections of the deposit taking in XUs 1 to 5 down to a depth of $8 \mathrm{~cm}$ and $20 \%$ of the excavated deposit (by volume) contained nearly all bone (82\%) and marine shell (99.9\%) but only $5.2 \%$ of stone artefacts (by number) and $1.7 \%$ of ochre. In contrast, XUs 6 to 16 located 8 to $46 \mathrm{~cm}$ below the surface and representing $72.2 \%$ of excavated deposit (by volume) contained most stone artefacts $(93.1 \%$ by number) and most ochre (93.9\%).

\section{Ochres}

Ochre is mostly in the form of red (haematite) small fragments a well-known pigment type for the region (McNiven and David 2004). The six fragments of facetted red ochre were recovered from Square C (Table 1). These facetted ochres are consistent with ochre grinding and the preparation of red pigment at the site. Identification of non-facetted (unmodified) ochre was restricted to fragments soft enough to be fingernail scratched. As such, all fragments of identified ochre are considered pigments suitable for the production of paint and rock art (see Henshilwood et al. 2001:431).

That the in situ ochres are functionally related to the adjacent paintings is supported further by spatial proximity and similar Munsell colour code determinations. The six facetted pieces of ochre range in colour from dark red (10R 3/6, $n=4)$, dusky red $(10 \mathrm{R} 3 / 4)$ to red $(10 \mathrm{R} 4 / 6)$ (Table 1). In lieu of Munsell colour determinations taken directly from paintings in the field, five indicative Munsell readings were made for five separate paintings using digital photographs adjusted according to the IFRAO Standard Scale (Bednarik and Seshadri 1995): Crayfish (\#31) (weak red, 10R 5/4), Canoe (\#34) (pale red, 10R 6/3), Canoe (\#37) (pale red, 10R 6/3), Canoe (\#39) (weak red, 10R 5/3) and a Fish/Dugong (\#38) (weak red, 10R 5/4). The Munsell determinations indicate that the colours of the facetted ochre pieces and rock paintings all have the same Hue: red (10R) (see also Thorn 2008). The lack of any major colour differences (e.g. bright pink, deep mulberry) is consistent with an association between the buried ochre fragments and adjacent paintings.

Differences in Munsell colour Value and Chroma between the in situ facetted ochres and wall paintings are consistent with differing weathering contexts. The colours of the wall paintings are lighter (higher Values) and less vivid (lower Chroma) compared to the buried in situ ochres. This pattern is consistent with the wall paintings being exposed directly to both anthropogenic and natural factors (especially the elements) for over 1000 years. Such exposure would result in paintings becoming increasingly weathered through time with increasing deterioration of painted surfaces in the form of pigment loss as a result of micro-spalling of granite substrate (Thorn 2008). As Bednarik (2007:12) cogently notes: 'iron oxides and hydroxides are highly susceptible to chemical alterations that inevitably involve changes in reflective properties (colour), and it is naïve even to assume that either the pigment on the wall or the pigment 
in the ground would retain the original colour. Both are likely to be modified differently'.

\section{Taphonomic Considerations}

Disturbance to sediments observed during excavation was minor and limited to faunal turbation in the form of isolated small termite tunnels and isolated small $(0.5 \mathrm{~cm}$ diameter $)$ burrows, and floral turbation stemming from rootlets (throughout the deposit) and a few scattered larger roots (up to $2 \mathrm{~cm}$ in diameter). Termite tunnels were observed running horizontally along the granite shelter wall on the east edge of Squares A and/or B in XUs 2, 3, 4, 6, 9, 12, 13 and 14 and Squares C and D in XUs 2, 3, 11 and 12. Most of these tunnels developed overnight during fieldwork. Areas of termite disturbance were discarded. Other insect burrows were restricted to the upper $10 \mathrm{~cm}$ of deposit in XUs 2, 3, 5 and 6. For example, a live cicada nymph (Cicadidae) was recorded in XU5 (Square D) while live ants were observed in XU6 (Square C).

Restriction of food remains (marine shell and bone) to upper levels of the site (XUs 1 to 4) may be taphonomic (i.e. reflect loss of these materials due to acidic conditions in older deposits). However, there is no $\mathrm{pH}$ shift indicating buffering through carbonate dissolution below XU4. Poor preservation is indicated by the reduction of the fish bone assemblage to tooth enamel - a condition consistent with acidic sediments and poor faunal preservation. Bivalve shells in XU4 were in original depositional context as they were lying flat (i.e. horizontal and parallel to the ground surface). This problem requires further investigation, and with hindsight, microscopic examination of resin-impregnated samples of soil fabric might assist in resolving degradation pathways for shell.

Differential preservation is unlikely to be responsible for vertical changes in the density of charcoal, stone artefacts and ochre through the deposit. While rock and sediment data reveal an overall stratigraphic integrity to the deposit (see above), the pattern of vertical changes in stone artefact densities is a normal distribution curve centring on XU9 and slightly skewed to the bottom (Figure 9). This pattern is consistent with gradual post-depositional movement of artefacts both above and below an original artefact concentration centring on XU9 (e.g. Brantingham et al. 2007; Hofman 1986; Morin 2006; Rowlett and Robbins 1982). Post-depositional dissipation is most apparent in the lower levels of the deposit (XUs 13-20) which feature only tiny artefacts averaging $0.04 \mathrm{~g}$ whereas artefacts in the upper levels of the deposit (XUs 1-12) have a higher mean weight of $0.24 \mathrm{~g}$ (Figure 10). This apparent size-sorting of artefacts is consistent with known selective downward movement of tiny artefacts in archaeological deposits through invertebrate bioturbation, rootlet penetration, rainwater percolation and treadage (e.g. Armour-Chelu and Andrews 1994; Canti and Piearce 2003; McBrearty 1990; Peacock and Fant 2002; Piearce 1984; Stockton 1973; van Nest 2002). As most stone artefacts within lower levels of the deposit (XUs 13-20) probably derive from higher levels of the deposit, they cannot be considered chronologically and behaviourally separate from upper level artefacts.

An implication of hypothesised post-depositional movement of tiny stone artefacts is that other cultural materials such as charcoal and ochre may have experienced similar downward vertical displacement, especially as micro-fabric fragments. As

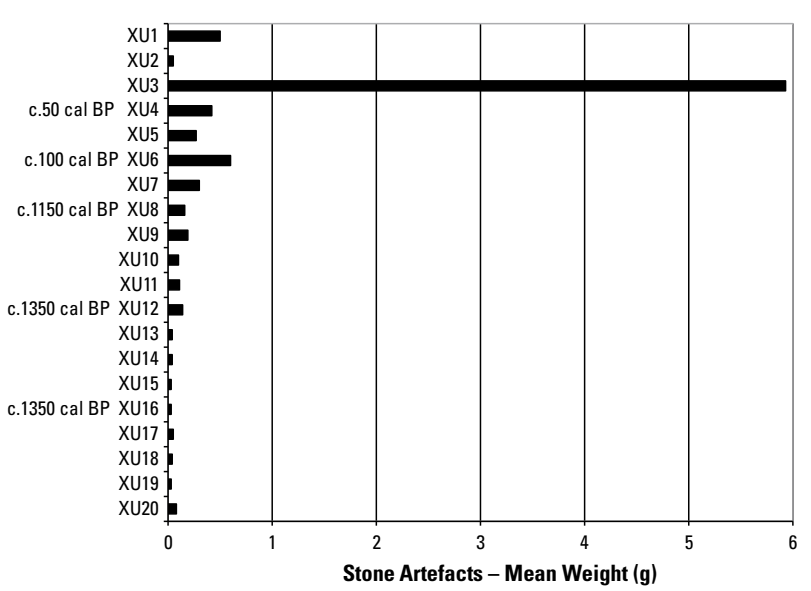

Figure 10 Vertical changes in stone artefact mean weight, Squares A to D combined, Kabadul Kula.

such, some charcoal and ochre fragments in lower sections of the deposit may similarly have an original in situ (depositional and discard) context in levels above XU13. However, unlike stone artefacts, density peaks in charcoal and ochre also occur well below XU9 suggesting the presence of original concentrations (i.e. primary stratification) of charcoal and ochre (including large pieces of facetted ochre) in lower levels of the deposit. The overall integrity of lower level ochre and charcoal assemblages is consistent with the rock data which reveals no major postdepositional disturbance within the excavated deposit (see above). Other studies have shown how small particles in sites may move vertically while larger artefacts remain in situ (Boulter et al. 2006:10). Taking these taphonomic issues into consideration, the following site function and discard events can be inferred: lower levels of the site reveal a focus on ochre and painting activity; upper levels of the site show a broadening of activities that included ochre use and manufacture and use of stone artefacts. Subsistence activities (e.g. consumption of turtle/ dugong, fish and shellfish) were a feature of recent occupation of the site and possibly during earlier periods of site use.

\section{Radiocarbon Dating and Chronology}

Chronology of the cultural deposit was determined from six AMS radiocarbon dates on charcoal - five from Square C and one from Square A (Table 2). Four of the dates were on fragments of carbonised seed and two dates were on fragments of wood charcoal. Dating was undertaken by the University of Waikato Radiocarbon Dating Laboratory in New Zealand. Radiocarbon dates were calibrated into calendar years using the online calibration programme Calib 5.0.2 (Stuiver and Reimer 1993;

Table 1 Facetted ochre fragments from Kabadul Kula.

\begin{tabular}{|c|c|c|c|c|}
\hline Sq-XU & $\begin{array}{c}\text { Item } \\
\#\end{array}$ & $\begin{array}{l}\text { Weight } \\
\text { (g) }\end{array}$ & $\begin{array}{l}\text { Max. } \\
\text { Length } \\
\text { (mm) }\end{array}$ & $\begin{array}{l}\text { Munsell } \\
\text { Colour }\end{array}$ \\
\hline $\mathrm{C}-8$ & 1 & 2.74 & 22.5 & 10R 3/6 (dark red) \\
\hline C-8 & 2 & 0.77 & 15.2 & 10R 3/6 (dark red) \\
\hline $\mathrm{C}-8$ & 3 & 0.43 & 9.9 & 10R 3/6 (dark red) \\
\hline C-11 & 1 & 4.51 & 26.9 & 10R 3/6 (dark red) \\
\hline $\mathrm{C}-12$ & 1 & 0.33 & 10.8 & 10R 3/4 (dusky red) \\
\hline$C-16 b$ & 1 & 5.39 & 39.1 & 10R 4/6 (red) \\
\hline
\end{tabular}


Stuiver et al. 2005) and the Southern Hemisphere calibration dataset (ShCal04) (McCormac et al. 2004). For convenience and heuristic purposes, a single, central best-point estimate was calculated for the probability distribution of each date using the median calibrated age (following Telford et al. 2004). These single dates are expressed as 'years ago' (cal BP - i.e. before AD 1950) and have been rounded to the nearest 50 years to emphasise their approximate (circa) status. All dates reveal increasing age with depth indicating that the vertical structure of the deposit is largely depositional and consistent with the law of superposition.

XUs 4 and 6 taking in the upper $10 \mathrm{~cm}$ of deposit and nearly all bone and marine shell produced dates of $75 \pm 30$ BP (Wk22804) and $99 \pm 36 \mathrm{BP}$ (Wk-22805) respectively and most likely represent the nineteenth century AD. XU8 at a depth of $13-16 \mathrm{~cm}$ below the surface produced a date of $1276 \pm 30 \mathrm{BP}$ (c.1150 years ago) (Wk-22806) indicating that a hiatus of around 1000 years exists in sediments spanning XUs 6 to 8 (i.e. between $8 \mathrm{~cm}$ and $16 \mathrm{~cm}$ below the surface). While this hiatus is not represented stratigraphically, the transition from XU8 to XU6 is marked by a decrease in the density of charcoal and a dramatic decrease in the density of stone artefacts and ochre fragments (Figure 9). The absence of a relative concentration peak in cultural (e.g. stone artefacts and ochre fragments) and non-cultural (granitic rock fragments, including roof fall and in-washed gravels) materials in XU7 corresponding to a lag deposit (Figures 7 and 9) suggests strongly that the chronological hiatus represents a disconformity associated with minimal net sediment accumulation and cultural discard at the site and not selective removal of sediments by erosion (see Kelly et al. 2006; O'Connor et al. 1999).

The remaining two Holocene dates of $1508 \pm 32$ BP (Wk22807) and $1533 \pm 30 \mathrm{BP}(\mathrm{Wk}-22808)$ from XUs 12 and $16 \mathrm{~b}$ located $26-29 \mathrm{~cm}$ and $40-43 \mathrm{~cm}$ below the surface respectively produced identical calibrated dates of c.1350 years ago, suggesting rapid deposition at this time. Thus, the bulk of the excavated deposit located in XUs 8 to $16 \mathrm{~b}$ located $13-43 \mathrm{~cm}$ below the surface date to between 1150 and 1350 years ago (and between 1062 and $1415 \mathrm{cal} \mathrm{BP}$ at two sigma). The upper four AMS dates are considered reliable age estimates for associated sediments and cultural materials given that they were based on seeds and thus do not have an inbuilt 'old wood' problem.

A basal age determination of 23,869 260 BP (Wk-23692) was obtained for XU20 in Square A located $11 \mathrm{~cm}$ below the age determination of $1533 \pm 30 \mathrm{BP}(\mathrm{Wk}-22808)$ in XU16b. This Pleistocene determination is beyond calibration using Calib 5.0.2 but probably dates to around 30,000 years ago following Hughen et al. (2006). While a jump in age of more than 22,000 radiocarbon years over a vertical distance of $11 \mathrm{~cm}$ or less has been demonstrated at other archaeological sites in northern Australia (e.g. Balme 2000; David et al. 1997), it is unlikely that Wk-23692 reflects the age of surrounding sediments (and associated cultural materials) within XU20. The lack of any obvious visual stratigraphic change between Wk-23692 and Wk-22808, absence of saprolite and broad similarities in the frequency of charcoal, stone artefacts and ochre across the same sediments is inconsistent with a stratigraphic disconformity and major chronological hiatus (see O'Connor et al. 1999). While XU20 registers a relative increase in rock (granite gravel) density (Figure 7), it is clear that this concentration relates to the basal bed and not the net result of over 20,000 years of rock accumulation within the site. Parsimony suggests that the single charcoal fragment upon which Wk-23692 is based washed into the site sometime around 1500 years ago, probably derived from eroding

Table 2 Radiocarbon AMS dates for Kabadul Kula $\left({ }^{*} \delta^{13} \mathrm{C} \%\right.$ o measured by the accelerator but not reported).

\begin{tabular}{|c|c|c|c|c|c|c|c|c|c|c|}
\hline $\begin{array}{l}\text { Lab. } \\
\text { No. }\end{array}$ & Square & $\mathbf{X U}$ & $\begin{array}{l}\text { Depth } \\
\text { (cm) }\end{array}$ & Sample & $\begin{array}{l}\delta^{13} \mathrm{C} \% \\
( \pm 0.2)\end{array}$ & $\begin{array}{l}{ }^{14} \mathrm{C} \text { Age } \\
\text { (years BP) }\end{array}$ & $\begin{array}{c}\text { Calibrated } \\
\text { Age BP } \\
1 \sigma \\
\text { (probabilities) }\end{array}$ & \begin{tabular}{|c|} 
Calibrated \\
Age BP \\
$2 \sigma$ \\
(probabilities)
\end{tabular} & $\begin{array}{c}\text { Calibrated } \\
\text { Age BP } \\
\text { Median }\end{array}$ & $\begin{array}{l}\text { Years } \\
\text { Ago } \\
\text { (cal BP) } \\
\text { circa }\end{array}$ \\
\hline Wk-22804 & $\mathrm{C}$ & 4 & $2.8-4.0$ & $\begin{array}{c}1 \\
\text { fragment } \\
\text { of seed }\end{array}$ & -26.2 & $75 \pm 30$ & $\begin{array}{c}0-0(0.138) \\
28-59(0.545) \\
119-136(0.288) \\
233-237(0.029)\end{array}$ & $\begin{array}{c}0-0(0.116) \\
5-13(0.015) \\
17-73(0.466) \\
82-106(0.064) \\
111-141(0.257) \\
227-251(0.082) \\
\end{array}$ & 57 & 50 \\
\hline Wk-22805 & C & 6 & 7.6-10.2 & $\begin{array}{c}2 \\
\text { fragments } \\
\text { of seed }\end{array}$ & -24.5 & $99 \pm 36$ & $\begin{array}{c}0-0(0.032) \\
26-71(0.497) \\
84-87(0.019) \\
94-103(0.064) \\
113-140(0.288) \\
229-242(0.101)\end{array}$ & $\begin{array}{c}0-143(0.860) \\
224-254(0.140)\end{array}$ & 86 & 100 \\
\hline Wk-22806 & C & 8 & $13.2-16.2$ & $\begin{array}{c}1 \\
\text { fragment } \\
\text { of seed }\end{array}$ & -26.1 & $1276 \pm 30$ & $\begin{array}{c}1078-1178 \\
(0.969) \\
1214-1219 \\
(0.031)\end{array}$ & $\begin{array}{c}1062-1188 \\
(0.784) \\
1200-1260 \\
(0.216)\end{array}$ & 1146 & 1150 \\
\hline Wk-22807 & C & 12 & $25.9-29.4$ & $\begin{array}{c}2 \\
\text { fragments } \\
\text { of seed }\end{array}$ & -23.5 & $1508 \pm 32$ & $\begin{array}{c}1307-1360 \\
(1.000)\end{array}$ & $\begin{array}{c}1298-1398 \\
(1.000)\end{array}$ & 1343 & 1350 \\
\hline Wk-22808 & C & $16 b$ & $40.0-42.5$ & $\begin{array}{c}3 \\
\text { fragments } \\
\text { of wood }\end{array}$ & $-^{*}$ & $1533 \pm 30$ & $\begin{array}{c}1330-1392 \\
(1.000)\end{array}$ & $\begin{array}{c}1300-1415 \\
(1.000)\end{array}$ & 1362 & 1350 \\
\hline Wk-23692 & $A$ & 20 & $53.7-59.2$ & $\begin{array}{c}1 \\
\text { fragment } \\
\text { of wood }\end{array}$ & -25.2 & $23,869 \pm 260$ & - & - & - & - \\
\hline
\end{tabular}


Pleistocene soils located upslope and further inland. However, final resolution of the status of this Pleistocene date will require further excavations and geomorphological investigations at the site, and its immediate environs.

\section{Antiquity of Ochre and Paintings}

Most ochre $(71.8 \%)$ and all pieces of facetted ochre were recovered from XUs 8 to 16 dating to within the restricted timeframe of between c. 1150 and c. 1350 years ago. After a hiatus in occupation between c. 1150 and c.100 years ago (XU7), only $8.7 \%$ of recovered ochres date to the past 100 years within XUs 1 to 6 . Similarly, little ochre (4.4\%) was recovered in levels dating to before c.1350 years ago in XUs 17 to 20. These results suggest strongly that not only did the c.200 year period between c. 1150 and c.1350 years ago represent the major phase of painting activity at Kabadul Kula, but that such painting activity also involved production of at least some of the extensive rock art at the site. The occupation phase probably increased net sediment accumulation at the site. As XUs 12 to 16 also take in the lower sections of the stone alignment, it is likely that this feature was constructed at or before c. 1350 years ago.

\section{Discussion and Conclusion}

Excavations at Kabadul Kula reveal that people were using ochre and most likely creating rock art at the site c.1150-1350 years ago. This inference is based on meeting, to various degrees of satisfaction, the six methodological conditions established for associating ochre paintings with in situ ochres at the site. Supportive evidence for acceptance of rock art dating at Kabadul Kula include: in situ ochres located directly below paintings (Condition 1); in situ ochres restricted to a narrow timeframe (Condition 4); in situ ochre concentration neither a product of erosion (Condition 5) nor bioturbation (Condition 6). Unfortunately, no fragments of rock art were found associated with in situ ochres (Condition 3). While insights into the functional association of painted ochres with in situ ochres at the site would be enhanced greatly by geochemical fingerprinting (Condition 2), such an association is consistent with Munsell colour similarities between the two ochre sets. Further research at Kabadul Kula will test this association more directly by geochemically characterising ochres from selected paintings and in situ ochres.

That Kabadul Kula was a site of high level ochre use and pigment production on Dauan is indicated by comparisons with Dauan 4, an open midden site located on the west coast of the island. Excavations at Dauan 4 recovered $4.4 \mathrm{~g}$ of ochre from 773.9 litres of excavated deposit, representing a density of $0.06 \mathrm{~g} / 10$ litres (McNiven 2006). In marked contrast, the density of ochre at Kabadul Kula is $4.81 \mathrm{~g} / 10$ litres, which is 80 times that seen at Dauan 4. Clearly, Kabadul Kula rock art site exhibits a much greater quantity of ochre compared to an open settlement site. Such differences indicate the special status of Kabadul Kula as a place of pigment production and use, a finding consistent with extensive rock art at the site.

The Kabadul Kula results represent the earliest available information on the antiquity of rock art in Torres Strait and indicate that in certain contexts exposed rock paintings in this coastal region can survive the harsh tropical climate (heavy rains) for over 1000 years. Along with the recent suggested rock paintings of c.500-700 years ago at Tigershark Rockshelter on Pulu islet to the south (McNiven et al. 2008), the Kabadul Kula findings reveal that the region's rock art can be historicised beyond the last couple of hundred years to investigate longterm changes in artistic traditions, place marking strategies and associated symbolic and socio-religious behaviours.

Despite the identification of c.1150-1350 year old rock art at Kabadul Kula, determining which paintings can be associated with this early phase of artistic activity is fraught with difficulty. While the condition of paintings at the site vary, associating degrees of weathering with age is potentially spurious given weathering at the site is also influenced by wall topography, aspect and relative exposure to the elements, especially rainfall runoff (McNiven et al. 2004). However, some degree of weathering control exists for the rock art panel adjacent to the excavation pit given consistency of topography, aspect and exposure to rainfall runoff. As such, it can be expected that some correlation exists between age of paintings and degree of weathering and fading. As three of the most faded paintings on the panel are canoes (Paintings \#34, 37 and 39) (McNiven et al. 2004:Table 1), canoe paintings may represent the earliest phase of painting on the panel dating to c.1150-1350 years ago (Figure 5). Significantly, one of the canoes appears to have a crab-claw sail, the nearest examples of which are associated with the ethnographicallyknown hiri ceramic traders of the Gulf of Papua (Dutton 1982; McNiven et al. 2004:244). While no ethnographic information is available to indicate hiri traders ventured westwards into Torres Strait, McNiven (2008) hypothesises that the Papuan Gulf art style once extended into Torres Strait over 1000 years ago (see also Brady 2005 for additional information on artistic links between Torres Strait and Papua New Guinea). Furthermore, David (2008:470) documents a major phase of settlement expansion and 'the establishment of antecedent trade partnerships' in the western Gulf of Papua between c.950 and 1450 years ago.

An inevitable question arising from our research is to what extent oral history of the Kiwai raiders can be associated with suggested $>1000$ year old paintings at Kabadul Kula. McNiven et al. (2004) hypothesised that paintings by the Kiwai raiders represent the most recent of at least two phases of painting at the site. As such, we suggest that $>1000$ year old rock art at Kabadul Kula pre-dates the Kiwai raiders story. This view is consistent with the generally faded paintings across the northwest panel where the excavation pit was located and the presence of clearer paintings (probably of more recent age and associated with the Kiwai raiders) on the northern panel. Whether or not excavation of sediments beneath the northern panel reveals evidence of a $<1000$ year old painting phase is a matter for future research. To what extent sediments beneath the northern panel have been compromised stratigraphically by extensive termite nest activity remains to be seen.

Refinements in understanding stratigraphic resolution at the site, and inferred social change through time from the artefact record require new approaches. Excavation techniques and AMS dating no longer constrain interpretive resolution adjacent to rock art panels in tropical Australian sites like Kabadul Kula. Primary knowledge gaps now lie in understanding sedimentation process, the source-pathways of sediments being deposited and the dearth of method and theory regarding the archaeological consequences of the activities of invertebrate 
biofauna and their influence on deposits, autecological traces and methods of trace-recognition (e.g. in resin-impregnated thin section). Kabadul Kula demonstrates the need for sitespecific microfaunal observational data (see Grave and Kealhofer 1999; Madge 1969) and the application of micromorphological techniques (Davidson and Simpson 2001; Matthews et al. 1997) for elucidating formation processes specific to soil fabrics (including micro-artefacts) in Australian tropical archaeological contexts, specifically for archaeological interpretation. This requires a return to 'actuopalaeontology' as advocated by Efemov (1940) and echoes a previous call to the Australian archaeological community (see Hiscock 1990). Recent advances in regolith dating and modelling (see Barrows et al. 2004; Chappell 2006; Wilkinson et al. 2005) and 're-discovery' of soil production functions (Humphreys and Marshall 2007) provide excellent platforms for retheorising soil-sediment accumulation models over bedrock specific to significant cultural deposit sequences adjacent to rock art panels such as those on Dauan.

Kabadul Kula reveals that people have been living on Dauan for at least c.1350 years. This date doubles the known antiquity of human occupation of the island revealed previously by excavations at Dauan 4 , the only other site excavated and radiocarbon dated on Dauan (McNiven 2006). Given that people were living on the nearby island of Saibai 2500-2600 years ago (Barham 1999; Barham et al. 2004), it is likely that occupational evidence of similar antiquity awaits discovery on Dauan. Our future excavations on Dauan are aimed at providing an expanded chronological framework from which we can better historicise and model the emergence of local rock art, midden and quarry sites within the broader social context of Torres Strait and neighbouring Papua New Guinea.

\section{Acknowledgements}

Kaima esso to the people of Dauan for their hospitality and for providing the special opportunity to research the history of Kabadul Kula. Ursula Pietrzak-Aniszewska (School of Geography and Environmental Science, Monash University) kindly undertook the particle size and $\mathrm{pH}$ analyses. Kara Rasmanis (School of Geography and Environmental Science, Monash University) kindly drafted the figures. Thanks to Marshall Weisler (School of Social Science, The University of Queensland) for identification of fish teeth and to Ken Aplin (Australian National Wildlife Collection, CSIRO Division of Sustainable Ecosystems) for identification of pig bone. This research was supported in part by ARC Discovery Projects Grant DP0344070 and a National Indigenous Heritage Program grant. The paper was improved by comments gratefully received from anonymous referees, Bruno David and Jo McDonald.

\section{Appendix}

Prior to analyses all soil samples were air-dried to constant weight at approximately $30^{\circ} \mathrm{C}$. Subsamples, c. $5 \mathrm{~g}$ of air-dry soil, were dispersed in distilled water (hot), and not subjected to any other chemical pre-treatment. The samples were wet sieved at $1000 \mu \mathrm{m}$. The retained particles were transferred to pre-weighed petri dishes, air-dried to constant weight, and weighted (particles $>1000 \mu \mathrm{m}$ ). The soil water suspension (particle $<1000 \mu \mathrm{m}$ ) was analysed using the Backman Culter LS 100 instrument. The particle size distribution was classified using the Standard
Association of Australia scheme (McDonald et al. 1998). The size fractions are defined as sand $(63-2000 \mu \mathrm{m})$, silt $(2-63 \mu \mathrm{m})$ and clay $(<2 \mu \mathrm{m})$. The sand size fraction (total sand) is a sum of coarse sand $(600-2000 \mu \mathrm{m})$, medium sand $(600-212 \mu \mathrm{m})$ and fine sand $(212-63 \mu \mathrm{m})$. The coarse, medium and fine sand size fractions are not directly equivalent to phi cut-offs or commonly adopted geoarchaeological standard limits for medium sand and fine sand which are $250-500 \mu \mathrm{m}$ and $125-250 \mu \mathrm{m}$ (see Gale and Hoare 1991; Goldberg and Macphail 2006; Rapp and Hill 2006:29-31). The overall range limits specified for clay, silt and sand size fractions are the same as in other international classification systems based on the Udden-Wentworth system (see Gale and Hoare 1991:58-62). No conversion to phi-scale is therefore undertaken. The fractions of clay, silt and sand (fine, medium and some coarse) size particles were calculated as volume percentage of the size fraction smaller than $1000 \mu \mathrm{m}$.

\section{References}

Armour-Chelu, M. and P. Andrews 1994 Some effects of bioturbation by earthworms (Oligochaeta) on archaeological sites. Journal of Archaeological Science 21:433-443.

Attenbrow, V., B. David and J. Flood 1995 Mennge-ya and the origins of points: New insights into the appearance of points in the semi-arid zone of the Northern Territory. Archaeology in Oceania 30(3):105-120.

Balek, C.L. 2002 Buried artifacts in stable upland sites and the role of bioturbation: A review. Geoarchaeology 17(1):41-51.

Balme, J. 2000 Excavations revealing 40,000 years of occupation at Mimbi Caves, south central Kimberley, Western Australia. Australian Archaeology 51:1-5.

Barham, A.J. 1999 The local environmental impact of prehistoric populations on Saibai Island, northern Torres Strait, Australia: Enigmatic evidence from Holocene swamp lithostraigraphic records. Quaternary International 59:71-105.

Barham, A.J., M.J. Rowland and G. Hitchcock 2004 Torres Strait bepotaim: An overview of archaeological and ethnoarchaeological investigations and research. In I.J. McNiven and M. Quinnell (eds), Torres Strait Archaeology and Material Culture, pp.1-72. Memoirs of the Queensland Museum, Cultural Heritage Series 3(1). Brisbane: Queensland Museum.

Barrows, T.T., J.O. Stone, L.K. Fifield and R.G. Cresswell 2004 Exposure ages for Pleistocene periglacial deposits in Australia. Quaternary Science Reviews 23:697-708.

Beckett, J. 1963 Rock art of the Torres Strait Islands. Mankind 6(2):52-54.

Bednarik, R.G. 2007 Rock Art Science: The Scientific Study of Palaeoart. New Delhi: Aryan Books International.

Bednarik, R. and K. Seshadri 1995 Digital colour re-constitution in rock art photography. Rock Art Research 12(1):42-51.

Binet, F. and R.C. Le Bayon 1999 Space-time dynamics in situ of earthworm casts under temperate cultivated soils. Soil Biology and Biochemistry 31(1):85-93.

Boulter, C.H., M.D. Bateman, A.S. Carr and C.D. Frederick 2006 Assessment of archaeological site integrity of sandy substrates using luminescence dating. Society for Archaeological Sciences Bulletin 29(2):8-12.

Brady, L.M. 2005 Painting Patterns: Torres Strait Region Rock Art, NE Australia. Unpublished PhD thesis, Monash University, Clayton.

Brady, L. 2006 Documenting and analysing rock paintings from Torres Strait, NE Australia, with digital photography and computer image enhancement. Journal of Field Archaeology 31(4):363-379.

Brady, L. 2007 A different look: Comparative rock-art recording from the Torres Strait using computer enhancement techniques. Australian Aboriginal Studies 1:98-115.

Brady, L. 2008 Symbolic language in Torres Strait, NE Australia: Images from rock art, portable objects and human scars. Antiquity 82(316):336-350. 
Brady, L., B. David, L. Manas and the Mualgal (Torres Strait Islanders) Corporation 2003 Community archaeology and oral tradition: Commemorating and teaching cultural awareness on Mua island, Torres Strait. The Australian Journal of Indigenous Education 31:41-49.

Brady, L., B. David, L. Manas, the Mualgal (Torres Strait Islanders) Corporation and I.J. McNiven 2004 Rock paintings of Mua island: Initial results from western Torres Strait. Rock Art Research 21(1):27-46.

Brady, L. and Kaurareg Aboriginal Community 2007 A middle ground? Recent archaeological investigations from the Kaurareg Archipelago, south-western Torres Strait, Queensland. Australian Archaeology 65:17-29.

Brantingham, P.J., T.A. Surovell and N.M. Waguespack 2007 Modelling postdepositional mixing of archaeological deposits. Journal of Anthropological Archaeology 26:517-540.

Brown, D.J., K. McSweeney and P.A. Helmke 2004 Statistical, geochemical, and morphological analyses of stone line formation in Uganda. Geomorphology 62:217-237.

Canti, M.G. 2003 Earthworm activity and archaeological stratigraphy: A review of products and processes. Journal of Archaeological Science 30:135-148.

Canti, M.G. 2006 Deposition and taphonomy of earthworm granules in relation to their interpretive potential in Quaternary stratigraphy. Journal of Quaternary Science 22(2):111-118.

Canti, M. and T. Piearce 2003 Morphology and dynamics of calcium carbonate granules produced by different earthworm species. Pedobiologia 47:511-521.

Chappell, J. 2006 Australian landscape processes measured with cosmogenic nuclides. In B. Pillans (ed.), Regolith Geochronology and Landscape Evolution, pp.19-26. Perth: CRC LEME.

Chippindale, C. and P.S.C. Taçon 1998 The many ways of dating Arnhem Land rockart, north Australia. In C. Chippindale and P.S.C. Taçon (eds), The Archaeology of Rock-Art, pp.90-111. Cambridge: Cambridge University Press.

Clottes, J. and J. Courtin 1996 The Cave Beneath the Sea: Paleolithic Images at Cosquer. New York: Harry N. Abrams.

Cole, N., A. Watchman and M.J. Morwood 1995 Chronology of Laura rock art. In M.J. Morwood and D.R. Hobbs (eds), Quinkan Prehistory: The Archaeology of Aboriginal Art in S.E. Cape York Peninsula Australia, pp.147-160. Tempus 3. St Lucia, QLD: Anthropology Museum, University of Queensland.

Crouch, J., I.J. McNiven, B. David, C. Rowe and M. Weisler 2007 Berberass: Marine resource specialisation and environmental change in Torres Strait over the past 4000 years. Archaeology in Oceania 42(2):49-64.

Darwin, C. 1881 The Formation of Vegetable Mould through the Action of Worms, with Observations on their Habits. London: John Murray.

David, B. 2002 Landscapes, Rock-Art and the Dreaming: An Archaeology of Preunderstanding. London: Leicester University Press.

David, B. 2008 Rethinking cultural chronologies and past landscape engagement in the Kopi region, Gulf Province, Papua New Guinea. The Holocene 18(3):463479.

David, B., J. Brayer, I.J. McNiven and A. Watchman 2001 Why digital enhancement of rock art works: Rescaling and saturation. Antiquity 75:781-792.

David, B. and D. Chant 1995 Rock Art and Regionalisation in N. Qld Prehistory. Memoirs of the Queensland Museum 37(2). Brisbane: Queensland Museum.

David, B. and H.Lourandos 1999 Landscape as mind: Land use, cultural space and change in north Queensland prehistory. Quaternary International 59:107-123.

David, B., I.J. McNiven and J. Brayer 2003 Invisible paintings. British Archaeology 73:14-15.

David, B., I. McNiven, V. Attenbrow, J. Flood and J. Collins 1994 Of Lightning Brothers and White Cockatoos: Dating the antiquity of signifying systems in the Northern Territory, Australia. Antiquity 68:241-251.

David, B., I. McNiven, J. Flood and R. Frost 1990 Yiwarlarlay 1: Archaeological excavations at the Lightning Brothers site, Delamere station, Northern Territory. Archaeology in Oceania 25(2):79-84.
David, B., I.J. McNiven, L. Manas, J. Manas, S. Savage, J. Crouch, G. Neliman and L. Brady 2004a Goba of Mua: Archaeology working with oral tradition. Antiquity 78:158-172.

David, B., I.J. McNiven, R. Mitchell, M. Orr, S. Haberle, L. Brady and J. Crouch 2004b Badu 15 and the Papuan-Austronesian settlement of Torres Strait. Archaeology in Oceania 39(2):65-78.

David, B., R. Roberts, C. Tuniz, R. Jones and J. Head 1997 New optical and radiocarbon dates from Ngarrabullgan Cave, a Pleistocene archaeological site in Australia: Implications for the comparability of time clocks and for the human colonisation of Australia. Antiquity 71:183-188.

Davidson, D.A. and I.A. Simpson 2001 Archaeology and soil micromorphology. In D.R. Brothwell and A.M. Pollard (eds), Handbook of Archaeological Sciences, pp.167-177. Chichester: John Wiley and Sons.

d'Errico, F. and A.Vilhena Vialou 2007 Reduction sequences of colorant materials: The rock art site of Santa Elina (Mato Grosso, Brazil). Rock Art Research 24(2):181-190

Dutton, T. (ed.) 1982 The Hiri in History: Further Aspects of Long Distance Motu Trade in Central Papua. Pacific Research Monograph 8. Canberra: Australian National University.

Efremov, I.A. 1940 Taphonomy: A new branch of palaeontology. Pan-American Geologist 74:81-93.

FAO-UNESCO 1988 Soil Map of the World. World Resources Report. Rome: FAO.

Flood, J. and N. Horsfall 1986 Excavation of Green Ant and Echidna Shelters, Cape York Peninsula. Queensland Archaeological Research 3:4-64.

Gale, S.J. and P.G. Hoare 1991 Quaternary Sediments: Petrographic Methods for the Study of Unlithified Rocks. London: Belhaven Press.

Goldberg, P. and R.I. Macphail 2006 Practical and Theoretical Geoarchaeology. Oxford: Blackwell Publishing.

Grave, P. and L. Kealhofer 1999 Assessing bioturbation in archaeological sediments using soil morphology and phytolith analysis. Journal of Archaeological Science 26:1239-1248

Henshilwood, C.S., J.C. Sealy, R. Yates, K. Cruz-Uribe, P. Goldberg, F.E. Grine, R.G. Klein, C. Poggenpoel, K. van Niekerk and I. Watts 2001 Blombos Cave, Southern Cape, South Africa: Preliminary report on the 1992-1999 excavations of the Middle Stone Age levels. Journal of Archaeological Science 28:421-44

Hiscock, P. 1990. A study in scarlet: Taphonomy and inorganic artefacts. In S Solomon, I. Davidson and D. Watson (eds), Problem Solving in Taphonomy: Archaeological and Palaeontological Studies from Europe, Africa and Oceania, pp.34-49. Tempus 2. St Lucia, QLD: Anthropology Museum, University of Queensland.

Hiscock, P. 2008 Archaeology of Ancient Australia. London: Routledge.

Hofman, J.L. 1986 Vertical movement of artefacts in alluvial and stratified deposits Current Anthropology 27(2):163-171.

Hughen, K., J. Southon, S. Lehman, C. Bertrand and J.Turnbul 2006 Marine-derived ${ }^{14} \mathrm{C}$ calibration and activity record for the past 50,000 years updated from the Cariaco Basin. Quaternary Science Review 25:3216-3227.

Humphreys, G.S. and M.T. Marshall 2007 The soil production function: A brief history and its rediscovery. Geoderma 139:73-78.

Humphreys, G.S. and P.B. Mitchell 1983 A preliminary assessment of the role of bioturbation and rainwash on sandstone slopes in the Sydney Basin. In R.W Young and G.C. Nanson (eds), Aspects of Australian Sandstone Landscapes, pp.6680. Wollongong, NSW: Australian and New Zealand Geomorphology Group.

Johnson, D.L. 2002 Darwin would be proud: Bioturbation, dynamic denudation, and the power of theory in science. Geoarchaeology 17(1):7-40.

Kelly, R.L., D.A. Byers, W. Eckerle, P. Goldberg, C.V. Haynes, R.M. Larsen, J. Laughlin, J.I. Mead and S. Wall 2006 Multiple approaches to formation processes: The Pine Spring Site, southwest Wyoming. Geoarchaeology 21(6):615-638.

Keyser, J.D. 2001 Relative dating methods. In D. Whitely (ed.), Handbook of Rock Art Research, pp.16-138. Walnut Creek, CA: AltaMira Press. 
Laade, W. 1971 Oral Traditions and Written Documents on the History and Ethnography of the Northern Torres Strait Islands, Saibai - Dauan - Boigu. Vol.1. Adi - Myths, Legends, Fairy Tales. Weisbaden: Steiner.

Lawrie, M. 1970 Myths and Legends of Torres Strait. St Lucia, QLD: University of Queensland Press.

Macintosh, N.W.G. 1965 Dingo and horned anthropomorph in an aboriginal rock shelter. Oceania 36(2):85-101.

Madge, D.S. 1969 Field and laboratory studies on the activities of two species of tropical earthworms. Pedobiologia 9:188-214.

Marshall, T.J. 1947 Mechanical Composition of Soil in Relation to Field Descriptions of Texture. CSIR Australia Bulletin 224. Melbourne : Council for Scientific and Industrial Research.

Matthews, W., C.A.I. French, T. Lawrence, D.F. Cutler and M.K. Jones 1997 Microstratigraphic traces of site formation processes and human activities. World Archaeology 29:281-308.

McBrearty, S. 1990 Consider the humble termite: Termites as agents of postdepositional disturbance at African sites. Journal of Archaeological Science 17:111-143.

McCormac, F.G., A.G. Hogg, P.G. Blackwell, C.E. Buck, T.F.G. Higham and P.J. Reimer 2004 SHCAL04 southern hemisphere calibration, 0-11.0 cal kyr BP. Radiocarbon 46:1087-1092.

McDonald, J. 2006 Rock-art. In J. Balme and A. Paterson (eds), Archaeology in Practice: A Student Guide to Archaeological Analyses, pp.59-96. Carlton: Blackwell.

McDonald,J.2008 Dreamtime Superhighway:Sydney Basin Rock Art and Prehistoric Information Exchange. Terra Australis 27. Canberra: ANU E Press.

McDonald, J. and P.Veth 2008 Rock-art of the Western Desert and Pilbara: Pigment dates provide new perspectives on the role of art in the Australian arid zone. Australian Aboriginal Studies 1:4-21.

McDonald, R.C., R.F. Isbell, J.G. Speight, J. Walker and M.S. Hopkins 1998 Australian Soils and Land Survey Field Handbook. Canberra: CSIRO.

McNiven, I.J. 2006 Dauan 4 and the emergence of ethnographically-known social arrangements across Torres Strait during the last $600-800$ years. Australian Archaeology 62:1-12.

McNiven, I.J. 2008 How old is the Papuan Gulf art style? A view from Torres Strait. Oceanic Arts Society Newsletter 13(5):8-9.

McNiven, I.J., J. Crouch, M. Weisler, N. Kemp, L. Clayton Martínez, J. Stanisic, M. Orr, L. Brady, S. Hocknull and W. Boles 2008 Tigershark Rockshelter (Baidamau Mudh): Seascape and settlement reconfigurations on the sacred islet of Pulu, western Zenadh Kes (Torres Strait). Australian Archaeology 66:15-32.

McNiven, I.J. and B. David 2004 Torres Strait rock-art and ochre sources: An overview. In I.J.McNiven and M. Quinnell (eds), Torres Strait: Archaeology and Material Culture, pp.209-225. Memoirs of the Queensland Museum, Cultural Heritage Series 3(1). Brisbane: Queensland Museum.

McNiven, I.J., B. David and L. Brady 2002 Torres Strait rock-art: An enhanced perspective. Australian Aboriginal Studies 2:69-74.

McNiven, I.J., B. David, L. Brady and J. Brayer 2004 Kabadul Kula: A rock-art site on Dauan Island, Torres Strait. In I.J. McNiven and M. Quinnell (eds), Torres Strait: Archaeology and Material Culture, pp.227-255. Memoirs of the Queensland Museum, Cultural Heritage Series 3(1). Brisbane: Queensland Museum.

McNiven, I.J., B. David and J. Brayer 2000 Digital enhancement of Torres Strait rock-art. Antiquity 74:759-760.

McNiven, I.J., W.R. Dickinson, B. David, M. Weisler, F. von Gnielinski, M. Carter and U. Zoppi 2006 Mask Cave: Red-slipped pottery and the Australian-Papuan settlement of Zenadh Kes (Torres Strait). Archaeology in Oceania 41(2):49-81.

Morin, E. 2006 Beyond stratigraphic noise: Unravelling the evolution of stratified assemblages in faunalturbated sites. Geoarchaeology 21(6):541-565.

Morwood,M.J.2002 Visions from the Past: The Archaeology of Australian Aboriginal Art. Crows Nest, NSW: Allen and Unwin.
Morwood, M.J. and L. Dagg 1995 Excavations at Yam Camp. In M.J. Morwood and D.R. Hobbs (eds), Quinkan Prehistory: The Archaeology of Aboriginal Art in S.E. Cape York Peninsula, Australia, pp.107-115. Tempus 3. St Lucia, QLD: Anthropology Museum, University of Queensland.

O'Connor, S. and B. Fankhauser 2001 Art at 40,000 BP? One step closer: An ochre covered rock from Carpenter's Gap Shelter 1, Kimberley Region, Western Australia. In A. Anderson, I. Lilley and S. O'Connor (eds), Histories of Old Ages: Essays in Honour of Rhys Jones, pp.287-300. Canberra: Pandanus Books.

O'Connor, S., P. Veth and A. Barham 1999 Cultural versus natural explanations for lacunae in Aboriginal occupation deposits in northern Australia. Quaternary International 59(1):61-70.

Peacock, E. and D.F. Fant 2002 Biomantle formation and artifact translocation in Upland sandy soils: An example from the Holly Springs National Forest, north central Mississippi, USA. Geoarchaeology 19(1):91-114.

Piearce, T.G. 1984 Earthworm populations in soils disturbed by trampling. Biological Conservation 29:241-252.

Rapp, G. and C.L. Hill 2006 Geoarchaeology: The Earth-Science Approach to Archaeological Interpretation. New Haven: Yale University Press.

Rayment, G.E. and F.R. Higginson 1992 Australian Laboratory Handbook of Soil and Water Chemical Methods. Melbourne: Inkata Press.

Rosenfeld, A. and M.A. Smith 2002 Rock art and the history of Puritjarra rock shelter, Cleland Hills, central Australia. Proceedings of the Prehistoric Society 68:103-124.

Rowlett, R.M. and M.C. Robbins 1982 Estimating original assemblage content to adjust for post-depositional vertical artefacts movement. World Archaeology 14(1):73-83.

Smith, M.A., B. Fankhauser and M. Jercher 1998 The changing provenance of red ochre at Puritjarra rock shelter, central Australia: Late Pleistocene to present. Proceedings of the Prehistoric Society 64:275-92.

Smith, M.A. and J. Ross 2008 Glen Thirsty: The history and archaeology of a Desert Well. Australian Archaeology 66:45-59.

Stein, J.K. 1983 Earthworm activity: A source of potential disturbance of archaeological sediments. American Antiquity 48:277-289.

Stockton, E.D. 1973 Shaw's Creek shelter: Human displacement of artefacts and its significance. Mankind 9(2):111-117.

Stuiver, M. and P.J. Reimer 1993 Extended ${ }^{14} \mathrm{C}$ database and revised CALIB radiocarbon calibration program. Radiocarbon 35:215-230.

Stuiver, M., P.J. Reimer and R.W. Reimer 2005 CALIB 5.0. Retrieved 17 September 2009 from http://calib.qub.ac.uk/calib/calib.html.

Telford, R.J., E. Heegaard and H.J.B. Birks 2004 The intercept is a poor estimate of a calibrated radiocarbon age. The Holocene 14(2):296-298.

Thorn, A. 2008 Kabadul Kula, Dauan Island: Report on Termite Nest Removal and Condition of the Site. Unpublished report to Dauan Island Community and Programme for Australian Indigenous Archaeology, School of Geography and Environmental Science, Monash University. North Melbourne: ARTCARE.

Vanderwal, R. 1973 The Torres Strait: Protohistory and beyond. University of Queensland, Anthropology Museum, Occasional Papers in Anthropology 2:157194.

Van Nest, J. 2002 The good earthworm: How natural processes preserve Upland Archaic archaeological sites of western Illinois, USA. Geoarchaeology 17(1):53 90.

Veth, P., M. Smith and M. Haley 2001 Kaalpi: The archaeology of an outlying range in the dunefields of the Western Desert, Australia. Australian Archaeology 52:9-17.

Wilkinson, M.T., J. Chappell, G.S. Humphreys, K. Fifield, B. Smith and P. Hesse 2005 Soil production in heath and forest, Blue Mountains, Australia: Influence on lithology and palaeoclimate. Earth Surface Processes and Landforms 30:923934 


\section{australian ARCHAEOLOGY}

The official journal of the Australian Archaeological Association Inc.

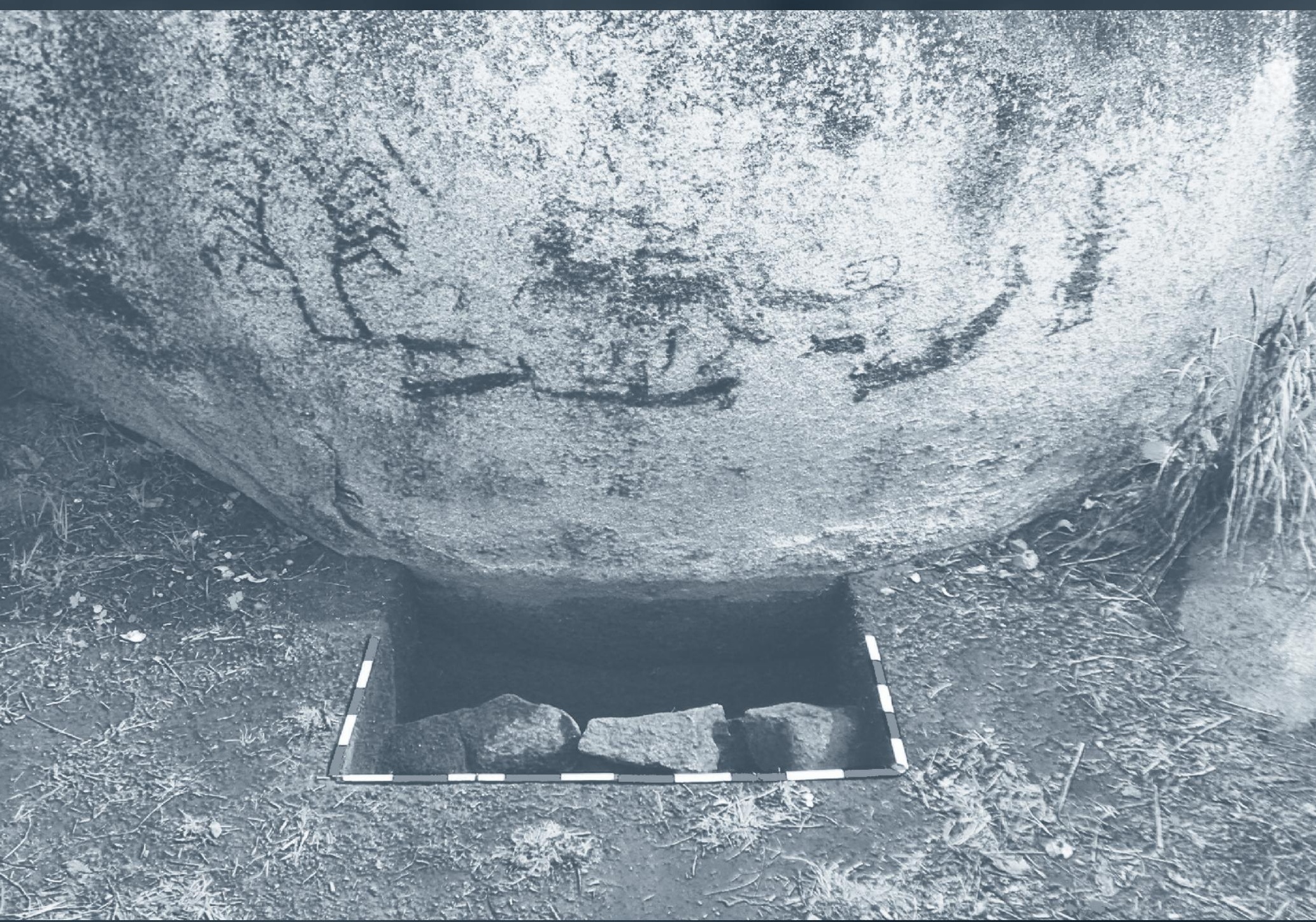

number 69 December 2009

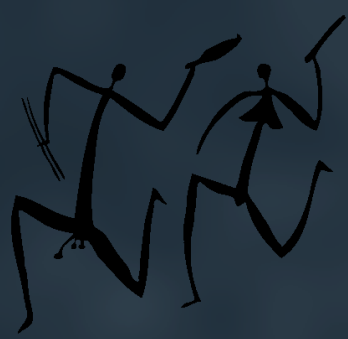




\section{australian ARCHAEOLOGY}

Australian Archaeology, the official publication of the Australian Archaeological Association Inc., is a refereed journal published since 1974. It accepts original articles in all fields of archaeology and othersubjectsrelevanttoarchaeological researchand practice in Australia and nearby areas. Contributions are accepted in six sections: Articles (5000-8000 words), Short Reports (1000-3000), Obituaries (500-2000), Thesis Abstracts (200-500), Book Reviews (500-2000) and Backfill (which includes letters, conference details, announcements and other material of interest to members). Australian Archaeology is published twice a year, in June and December.

Australian Archaeology is indexed in the Arts and Humanities Citation Index of the ISI Web of Knowledge, SCOPUS, Australian Public Affairs Information Service (APAIS), Anthropological Literature and Anthropological Index Online.

Australian Archaology is ranked as a tier A journal by the Australian Research Council, European Reference Index for the Humanities and French Agence d'Evaluation de la Recherche et de l'Enseignement Supérieur.

Subscriptions are available to individuals through membership of the Australian Archaeological Association Inc. or to organisations through institutional subscription. Subscription application/renewal forms are available at http://www.australianarchaeologicalassociation.com.au.

Graphic Design: Lovehate Design

Printing: $\quad$ Screen Offset Printing

Cover: Computer-enhanced photograph of northwest rock art panel at Kabadul Kula showing excavation pit with alignment of three granite boulders (Photograph: Ian J. McNiven)

All correspondence and submissions should be addressed to:

Australian Archaeology

PO Box 6088

St Lucia QLD 4067

AUSTRALIA

Email:journal@australianarchaeology.com

URL: http://www.australianarchaeologicalassociation.com.au

The views expressed in this journal are not necessarily those of the Australian Archaeological Association Inc. or the Editors.

\section{Editors}

Sean Ulm The University of Queensland

Annie Ross The University of Queensland

\section{Editorial Advisory Board}

Val Attenbrow Australian Museum

Margaret Conkey University of California, Berkeley

Bruno David Monash University

Andrew Fairbairn The University of Queensland

Richard Fullagar Scarp Archaeology

Martin Gibbs University of Sydney

Luke Godwin Central Queensland Cultural Heritage

Management Pty Ltd

Chris Gosden University of Oxford

Simon Holdaway University of Auckland

Susan Lawrence La Trobe University

Judith Littleton University of Auckland

Jo McDonald JMcD CHM Pty Ltd

\& Australian National University

Tim Murray La Trobe University

Jim O'Connell University of Utah

Fiona Petchey University of Waikato

Lynette Russell Monash University

Robin Torrence Australian Museum

Peter Veth Australian National University

\section{Editorial Assistant}

Linda Terry The University of Queensland

\section{Short Report Editors}

Lara Lamb University of Southern Queensland

Catherine Westcott Department of Transport

\& Main Roads (Q/d)

\section{Book Review Editors}

Jon Prangnell The University of Queensland

Jill Reid Department of Transport \& Main Roads (QId)

\section{Thesis Abstract Editor}

Stephen Nichols The University of Queensland 


\section{TABLE OF CONTENTS}

Editorial

Sean Ulm \& Annie Ross

ARTICLES

Excavations at Parnkupirti, Lake Gregory, Great Sandy Desert: OSL Ages for Occupation before the Last Glacial Maximum Peter Veth, Mike Smith, Jim Bowler, Kathryn Fitzsimmons, Alan Williams \& Peter Hiscock

A Re-Evaluation of 'Petroglyphs' on Blue Tier, Northeast Tasmania

Jo Field \& Peter D. McIntosh

Artefact Assemblage Characteristics and Distribution on the Point Blane Peninsula, Blue Mud Bay, Arnhem Land Patrick Faulkner \& Anne Clarke

Kabadul Kula and the Antiquity of Torres Strait Rock Art Ian J. McNiven, Liam M. Brady \& Anthony J. Barham

Archaeozoological Records for the Highlands of New Guinea: A Review of Current Evidence Alice Sutton, Mary-Jane Mountain, Ken Aplin, Susan Bulmer \& Tim Denham

Modernity and Tradition: Considerations of Cornish Identity in the Archaeological Record of a Burra Dugout Dean Mullen \& Peter J. Birt

\section{SHORT REPORTS}

An Engraved 'Archaic Face' in the Northeastern Simpson Desert

June Ross \& Mike Smith

Gledswood Shelter 1: Initial Radiocarbon Dates from a Pleistocene Aged Rockshelter Site in Northwest Queensland Lynley A. Wallis, Ben Keys, lan Moffat \& Stewart Fallon

\section{BOOK REVIEWS}

What's Changing: Population Size or Land-Use Patterns? The Archaeology of the Upper Mangrove Creek, Sydney Basin Reviewed by Brit Asmussen

Australia's Eastern Regional Sequence Revisited: Technology and Change at Capertee 3

Reviewed by Chris Clarkson

The Bone Readers: Atoms, Genes and the Politics of Australia's Deep Past

Reviewed by lain Davidson

Archaeology to Delight and Instruct: Active Learning in the University Classroom Reviewed by Martin Gibbs

The Roth Family, Anthropology, and Colonial Administration

Reviewed by Luke Godwin

A Critical Exploration of Frameworks for Assessing the Significance of New Zealand's Historic Heritage Reviewed by Jane Lennon

Place as Occupational Histories: An Investigation of the Deflated Surface Archaeological Record of Pine Point and Langwell Stations,

Western New South Wales, Australia

Reviewed by Ben Marwick

Aesthetics and Rock Art III Symposium: Proceedings of the XV UISPP World Congress

Reviewed by June Ross

Heritage, Communities and Archaeology

Reviewed by Amy Roberts

The Lost Legions: Culture Contact in Colonial Australia

Reviewed by Nan Rothschild

Climate Change: The Science, Impacts and Solutions

Reviewed by Michael J. Rowland

Time to Quarry: The Archaeology of Stone Procurement in Northwestern New South Wales, Australia

Reviewed by Justin Shiner

The Makers and Making of Indigenous Australian Museum Collections

Reviewed by Michael C. Westaway

THESIS ABSTRACTS

BACKFILL

Lectures

List of Referees

NOTES TO CONTRIBUTORS 